INTERNATIONAL JOURNAL OF RESEARCHES IN BIOSCIENCES, AGRICULTURE AND TECHNOLOGY (c) VISHWASHANTI MULTIPURPOSE SOCIETY (Global Peace Multipurpose Society) R. No. MH-659/13(N) www.vmsindia.org

\title{
BIOLOGICAL OXYGEN DEMAND AND CHEMICAL OXYGEN DEMAND CONTENT OF MULA DAM, RAHURI (M.S.), INDIA.
}

\author{
J. B. Musmade, J. R. Kakade, V. M. Pawar and V. B. Todmal \\ Arts Commerce and Science College, Sonai. Tal- Newasa, Dist- Ahmednagar.
}

\section{Abstract:}

The present scientific analysis deals with the study of B.O.D. and C.O.D. of Mula Dam, Rahuri (M.S.) India. The work was carried out during the year 2015 (January to December). The Mula Dam is mainly constructed for fishery and irrigation purpose. The result of the analysis showed that the C.O.D and B.O.D is maximum in summer while the values were observed minimum in monsoon and winter.

Keywords: C.O.D. - B.O.D.-Mula Dam.

\section{Introduction}

Water is life and pure water is basic need of life. Total life on earth depends on water which is used for domestic, industrial and agricultural purpose. Everything is originated in water and everything is sustain in water. Day by day pure water is getting polluted by various ways (Chemically and Biologically). Water pollution is excess addition of harmful ingredients which are harmful to the life to the water. Many workers proved that quality of water drops down due to pollution which affects the health. Quality of water varies from place to place and time to time due to interaction of local factors. Due to lack of knowledge about water quality and their causes the inhabitants are porn to diseases and health problems. The workers like Adebisi A. A. (1981), Khulbe (1993), Hanckok (1973), Mishra (1978), Mitra A. K. (1982) worked on water quality of various resources. There is noback record found about waret quality, C.O.D. and B.O.D. hence present work was undertaken.

\section{Materials and Methods}

Monthly samples were collected from Mula Dam for analysis in pre-cleaned 1 lit plastic bottle at morning hours and brought to the laboratories. For Biological Oxygen Demand samples were analysed with the hello of Winkler method and Chemical Oxygen Demand was measured by using dichromate digestion method. The analysis was done by using standard literature given by APHA (1985).

\section{Result and Discussion \\ Biological oxygen demand-}

It indicates the presence of biological matter in the water and expresses the degree of contamination. The value of B.O.D. varies from 3.3 to $26.6 \mathrm{mg} /$ lit. Were showed highest during monsoon and minimum in winter because of lesser quality of solids and microbial pollution.

\section{Chemical Oxygen Demand-}

It determines the oxygen required for chemical oxidation of organic matter with the help of strong chemical oxidant.

During the present work the C.O.D. values range from $4.5-49.8 \mathrm{mg} /$ lit. The maximum value is noted in monsoon due to inflow of organic dead matter and minimum was found in winter due to dilution effect.

\section{Acknowledgement}

The authors are thankful to the principal Dr. Kalhapure G. B., Vice Principal Dr. Tuwar A. R., Prof. Phatake V. R., Prof. Jangale M.S., Arts Commerce and Science College, Sonai for providing laboratory facility.

\section{References}

Adebisi, A.A.1981: The physic chemical hydrology of a tropical seasonal river upper ogum river nigerior hydrology a 70(2)157-165.

APHA 1985 Standard method for the examination of water and waste water. 16 th $\mathrm{Edn}$. APHA Washinten.

Hankock, F.D. 1973: Algal ecology of a stream polluted through gold mining with water streem and hydrobiology 43, 189-229.

Khubale R. D. And Durgapoal A., 1993: evolution of drinking water quality at bhimtal national, uttar pardesh Poll R S.5.21 (2): 109-111.

Mishra G.P. and Yadav A.K. 1978: A comparative study of physic-chemical characteristics of river $\&$ Lake water in central India. Hydrobiologia 59(30): 275-278.

Mitra A. K. 1982: Chemical characteristics of stations in the river Godavari, Krishna and Tungabhadra India, J. Environ Health 24 (2): 165; 179.

Table-1, B.O.D. and C.O.D. in water of Mula Dam (2013)

\begin{tabular}{|l|l|l|l|l|l|l|l|l|l|l|l|l|}
\hline Month & Jan & Feb & Mar & Apr & May & June & July & Aug & Sept & Oct & Nov & Dec \\
\hline Parameter & & & & & & & & & & & & \\
\hline B.O.D & 9.1 & 12 & 24.6 & 24.8 & 23.2 & 22.0 & 3.3 & 3.8 & 3.6 & 3.8 & 4.6 & 5.5 \\
\hline C.O.D & 10.2 & 26.5 & 49.8 & 47.1 & 35.3 & 32.1 & 4.5 & 4.5 & 4.9 & 5.1 & 9.2 & 9.4 \\
\hline
\end{tabular}

